\title{
ПРАВОВЫЕ ПОДХОДЫ СОВЕТА ЕВРОПЫ К РЕГУЛИРОВАНИЮ ВОПРОСОВ ДОНОРСТВА КРОВИ И ЕЕ КОМПОНЕНТОВ
}

\begin{abstract}
Аннотация: Предметом исследования автора выступает совокупность норм права, выработанные в рамках деятельности Совета Европь и регулирующих общественные отношения, связанные с донорством крови иее компонентов. В работе анализируются рекомендации, принятые Комитетом Министров Совета Европы, по различным аспектам донорства крови и ее компонентов, большая часть из которых до настоящего времени не переводилась на русский язык, а такжеключевые решения Европейского Суда по правам человека по изучаемому вопросу. В работе использованы какобщетеоретические, так и специально-юридические методы исследования, включая методы формальной логики, а также диалектический, формально-юридический и исторический методы. Первой международной организацией, в фокус внимания которой попала проблема донорства крови, стал Совет Европь (СЕ). Собственно Конвенция о защите прав и основных свобод человека, составляющая юридический фундамент правозащитной деятельности СЕ, не содержит положений, прямо регулируюших вопросы донорства. Однако этот пробел впоследствии был восполнен решениями Комитета Министров, а также правоприменительной практикой Европейского Суда по правам человека . В настоящей работе впервые проводится анализ указанных документов, позволяя сформировать представление о палитре норм СЕ, регулирующих вопросы донорства крови.

Abstract: The subject of this research is the complex of the legal norms, which were developed in the process of work of the Council of Europe and regulate social relations pertaining to the donation of blood and its components. This work analyzes the recommendations enacted by the Committee of Ministers of the Council of Europe on the various aspects of donation of blood and its components, the biggest part of which has not been translated into the Russian language until now; it also includes the key decisions of the Council of Europe on the human rights related to this topic. The Council of Europe became the first international organization that focused its attention on the issues of blood donation. The Convention for the Protection of Human Rights and Fundamental Freedoms, which acts as the juridical foundation of the human right advocacy of the Council of Europe, does not contain positions that would directly regulate the issues of donorship. This gap however, was later filled by the decisions of the Committee of Ministers, as well as the legal precedents of the European Court of Human Rights. This work is the first to analyze these documents, which allows forming the perception on the spectrum of norms of the Council of Europe that regulate the issues of blood donation. Ключевые слова: Медиинское право, биомедициское право, донорства крови, европейское право, международное право, Совет Европы, Комитет Министров, ЕСПЧ, ВИЧ, биобезопасность.
\end{abstract}

Keywords: Medical law, biomedical law, blood donation, European law, international law, Council of Europe, Committee of Ministers, European Court of Human Rights, HIV, biosafety.

истории человечества кровь всегда занимала особое место. Американский социолог D. Nelkin (1999), характеризуя место крови в культуре, писала, что метафорически кровь имеет различные, иногда противоречивые коннотации: это источник жизни и энергии, в то же время символ насилия и опасности. Она означает социальную солидарность, связь между индивидом и обществом, в то же самое время кровь - основание различия между людьми, напрямую связанное с политикой деления на расы и социальные классы ${ }^{1}$. Кровь составляет неотъемлемую часть множества ритуалов, имеющих место в различных культурах: напримep, R. Needham (1964) описывал ритуалы крови у пунанов (жители Борнео) $)^{2}$, V. Turner (1967) - у ндембу (Замбия) 3 . До

${ }^{1}$ Feldman E., Bayer R., ed. Blood feuds: AIDS, blood, and the politics of medical disaster. Oxford University Press. 1999, 291 p.

${ }^{2}$ Needham R. Blood, thunder and mockery of animals. Sociologus. 1964. 14 (2): 136-149

${ }^{3}$ Turner $V$. The forest of symbols: Aspects of Ndembu ritual. Cornell University Press. 1967, 405 p. настоящего времени отдельные индивиды, сдающие кровь, отмечают ритуальный и в известной степени священный характер донации ${ }^{4}$. Такой яркий культурологический окрас крови как субстанции не мог не транспонироваться в область донорства крови и ее компонентов. Достаточно лишь сказать, что в годы Второй мировой войны Конгресс США оказывал давление на Американский красный крест с тем, чтобы забор крови у чернокожих доноров не осуществлялся. Хотя этот запрет действовал лишь в первые годы войны, в последующие годы сегрегация чернокожих доноров сохранялась 5 . Европа не стала исключением. В Италии донорами, по данным Izzo U. (1999), становились преимущественно для членов своей семьи, как главного составного элемента общества, что вызвало в определенный момент дефицит донорской крови (до $75 \%)^{6}$.

${ }^{4}$ Charbonneau J., Tran N.Y. The symbolic roots of blood donation. Transfusion. 2013 Dec;53 Suppl 5:172S-9S.

${ }^{5}$ Love S. One Blood: The Death and Resurrection of Charles R. Drew. University of North Carolina Press, 1996. 373 p.

${ }^{6}$ Указ. Feldman E., Bayer R. (1999) 
DOI: $10.7256 / 1811-9018.2014 .12 .13523$

При цитировании этой статьи сноска на dоі обязательна

\section{Право и политика $12(180) \cdot 2014$}

Начиная с 90х годов 20го столетия в Европе имела место тенденция снижения количества доноров крови. Likatavicius G. et al. (2007) отмечает, что с 1990 по 2004 гг. в Восточной Европе количество доноров уменьшилось на 43 \%, в Центральной - на $26 \%$, в Западной - практически не изменилось. Одновременно с этим количество выявляемой ВИЧ инфекции при донациях резко возросло в Восточной Европе, Центральной осталось прежним и уменьшилось - в Западной Европе. ${ }^{7}$ Данные выводы подтверждает также Suligoi B. et al. (2010). ${ }^{8}$

Вероятно, первой международной организацией, в фокус внимания которой попала проблема донорства крови, стал Совет Европы. Собственно Конвенция о защите прав и основных свобод человека (ЕКПЧ), составляющая юридический фундамент правозащитной деятельности СЕ, не содержит положений, прямо регулирующих вопросы донорства. Однако этот пробел впоследствии был восполнен решениями Комитета Министров, а также правоприменительной практикой Европейского Суда по правам человека (ЕСПЧ). Какого-либо системного изучения данного массива правовых актов до настоящего времени не проводилось. Целью настоящей работы стал анализ указанных документов, который позволяет сформировать представление о палитре норм СЕ, регулирующих вопросы донорства крови.

Общественные отношения, связанные с донорством крови и ее оборотом, привлекли внимание Совета Европы (CE) в 50x годах прошлого века. Уже в 1958 году в рамках СЕ было разработано Европейское соглашение об обмене лекарственными веществами (therapeutic substances) человеческого происхождения. Под лекарственными веществами человеческого происхождения для целей Соглашения понимались кровь и ее дериваты, которые, согласно нормам данного международного акта, должны предоставляться сторонами друг другу в случае экстренной необходимости и при обеспечении внутренней потребности населения. При этом платы, кроме компенсации заготовки, переработки и хранения, взиматься не должно. Страна-получатель, при этом, должна гарантировать, что никакой выгоды не извлекается, и кровь (ее дериваты) передаются обозначенному государственному учреждению, а также сопроводить продукт сертификатом установленного образца. Протоколом к данному Соглашению, принятым в 1980 году, установлены довольно детальные требования к стандартизации указанных продуктов.

Начиная с 70х годов, Комитет Министров СЕ регулярно принимал рекомендации, затрагивающие сферу донорства крови. Правовым основанием для принятия таких актов служил пункт «b» статьи 15 Устава Совета Европы ${ }^{9}$, согласно которому в соответствующих случаях заключения Комитета Министров могут приобретать форму рекомендаций правительствам государств-членов. К настоящему моменту приняты 28 основных рекомендаций, затрагивающих вопросы донорства крови. Эти рекомендации, по нашему мнению, могут быть разделены на несколько тематических групп,

\footnotetext{
${ }^{7}$ Likatavicius G. et al. Trends in HIV prevalence in blood donations in Europe, 1990-2004.AIDS. 2007 May 11;21(8):1011-8.

${ }^{8}$ Suligoi B. et al.Epidemiology of human immunodeficiency virus infection in blood donations in Europe and Italy. Blood Transfus. $2010 \mathrm{Jul} ; 8(3): 178-$ 85. doi: 10.2450/2009.0126-09.
}

${ }^{9}$ Statute of the Council of Europe, London, 5.V.1949 регулирующих: гармонизацию законодательства в области изъятия и трансплантации материалов человеческого происхождения (резолюция (78) 29), права донора и реципиента (рекомендации (95) 14), ответственность властей (рекомендация (88) 4), проблемы ВИЧ-инфекции (рекомендации (83) $8,(85) 12,(87) 25,(89) 14,(94) 10)$, других инфекций и инвазий (рекомендации (81) 14, (84) 6, (2001) 4), самообеспеченность продуктами крови (рекомендация (90) 9), использование крови и ее компонентов (рекомендации (80) 5, (90) 9, (2002) 11), техническим аспектам заготовки, хранения, использования крови и ее компонентов (рекомендации (86) 6, (95) $15,(96) 11,(98) 10,(2003) 11)$, использование и банкирование стволовых клеток крови (рекомендации (98) 2, (2004) 8), предупреждение резус-конфликта (рекомендация (81) 5), подготовку специалистов (рекомендации (85)5, (2004) 18), проведение научных исследований и клинических испытаний (рекомендации (90) 3, (93) 4).

Представляется целесообразным кратко остановиться на основных требованиях, содержащихся в вышеуказанных документах.

Резолюция (78) 29 по гармонизации законодательства государств-членов касательно изъятия и трансплантации субстанций человеческого происхождения является базовым документом, устанавливающим список правил из 14 статей, в соответствие с которыми государствам-членам следует привести свое законодательство. Правила устанавливают необходимость полного информирования донора о медицинских, социальных и психологических последствиях изъятия субстанции, а также получения его согласия на такое изъятие. При этом в случае, если предполагается изъять нерегенерирующую субстанцию, такое согласие должно быть выражено в письменной форме. Такой подход сегодня используется во многих европейских странах, в частности, в Великобритании, где он был введен после начала эпидемии ВИЧ. Аналогичные нормы присутствуют и в законодательстве РФ. Кроме того, Правила предусматривают, что забор нерегенерирующих субстанций у живого донора возможен только в случае нахождения донора и реципиента в генетическом родстве, а также в исключительных случаях, когда имеются хорошие шансы на успех. В этом отношении российское законодательство является более категоричным, запрещая неродственные трансплантации и предотвращая, таким образом, продажу органов и тканей. Логичное исключение составляет кровь и ее компоненты, которые изначально заготавливаются для людей, не состоящих в родстве с донором.

Для недееспособных предусмотрены дополнительные гарантии. В случае, если изымаемая субстанция способна регенерировать, то забор осуществляется для лечебных и диагностических целей с согласия законного представителя при отсутствии возражения со стороны самого недееспособного; если забор представляет риск для здоровья, необходимо получение разрешения компетентного государственного органа. В случае, если изымаемая субстанция не способна регенерировать, то по общему правилу такое изъятие запрещено. Однако оно может быть допущено государством для терапевтических или диагностических целей в случае согласия донора, понимающего последствия принимаемого им решения, согласия законного представителя и компетентного государственного органа, при условии, что донор и 
реципиент находятся в тесной генетической связи. В случае риска для жизни и здоровья недееспособного донора изъятие запрещается.

Преломляя эти правила для случаев донорства крови и ее компонентов, можно прийти к выводу, что поскольку кровь регенерирует, то национальное законодательство о донорстве может допускать к участию в осуществлении донорской функции недееспособных при условии согласия их законных представителей и отсутствии возражения самих недееспособных. Вместе с тем, Федеральный закон «О донорстве крови и ее компонентов» ограничивает круг лиц, могущих быть донорами, только дееспособными. Следует признать, что такой подход обеспечивает достаточно высокую степень защиты прав недееспособных. Однако принимая во внимание право несовершеннолетних старше 15 лет (больных наркоманией старше 16 лет) на информированное добровольное согласие на медицинское вмешательство или на отказ от него, а также на вводимую Федеральным законом от 30.12.2012 № 302-Ф3 ${ }^{10}$ ограниченную дееспособность лиц с психическими заболеваниями (в развитие постановления Конституционного Суда РФ от 27.06.2012 № 15- $\left.{ }^{11}\right)$, представляется целесообразным все же допустить как несовершеннолетних старше 15 лет, так и ограничено дееспособных к осуществлению донорской функции при условии согласия их самих и законного представителя (для ограниченно дееспособного).

Рекомендация (95) 14 о защите здоровья доноров и реципиентов при переливании крови устанавливает целый ряд ключевых принципов донорства. Так, донации крови, плазмы или клеточных компонентов должны соответствовать принципам добровольного безвозмездного донорства, применимого к заготовке и трансплантации всех органов и тканей. Безвозмездность понимается при этом как отсутствие каких-либо материальных стимулов в форме денег или иной форме (за исключением небольших сувениров, напитков и покрытия транспортных расходов донора). Федеральный закон «О донорстве крови и ее компонентов» одним из принципов донорства крови ее компонентов в России называет поощрение и поддержку безвозмездного донорства крови и (или) ее компонентов. Кроме того, закон делегирует Министерству здравоохранения РФ как федеральному органу, осуществляющему функции по выработке государственной политики и нормативно-правовому регулированию в сфере здравоохранения, полномочия по установлению исчерпывающего перечня случаев, когда возможна сдача крови и ее компонентов за плату, размера платы (приказ Минздрава России от 17.12.2012 № 1069н), а также определению случаев возможности замены бесплатного питания донора (по установленному пищевому рациону донора) денежной компенсацией и порядка установления ее размера, эквивалентного стоимости примерного пищевого рациона донора, сдавшего кровь или ее компоненты безвозмездно (приказ Минздрава России от 26.04.2013 № 265н). Отмена платы за цельную кровь (возможность платы за донации методом афереза и редкие группы была сохранена) вызвала горячие общественные дискуссии, завершившиеся поручением Президента РФ В.В. Путина дополнительно

\footnotetext{
${ }^{10}$ Собрание законодательства РФ, 31.12.2012, № 53 (ч. 1), ст. 7627

${ }^{11}$ Вестник Конституционного Суда РФ, № 5, 2012
}

проработать данный вопрос ${ }^{12}$. Во исполнение поручения Минздрав России издал приказ от 26 апреля 2013 г. № 265н, которым было разрешено по письменному заявлению донора заменять питание денежной компенсацией.

Установление принципа безвозмездности донации влечет необходимость поиска альтернативных стимулов для привлечения новых доноров и формирования «кадровых» на основе научных данных. На решение вновь сдать кровь, по данным Schlumpf K.S. et al. (2008), в большей степени влияют наличие предыдущего опыта сдачи крови, изначальное желание вернуться, удобство места сдачи крови (отдаленность учреждения и т.д.). При этом альтруизм, социальная ответственность, сочувствие, высказанные как основание кроводачи, достоверно не влияют на вероятность вновь стать донором $^{13}$. B свою очередь Nguyen D.D. et al. (2008) связывают вероятность последующей донации преимущественно с удовлетворенностью от предыдущей. Одним из важнейших стимулов к последующей донации, согласно результатам авторов, является также медицинское обследование, предшествующее осуществлению донорской функции. ${ }^{14}$ Анализируя психологический аспект повторных донаций, Masser B.M. et al. (2008) пришли к выводу, что принципиальным моментом является перемена мотивации и становление самоидентичности в качестве донора крови. ${ }^{15}$

Из принципа безвозмездности, а также из самого факта человеческого происхождения крови вытекает необходимость оптимального ее использования и минимизации потерь. Рекомендация (2002) 11, определяя целый спектр мер, направленных на улучшение эффективности использования крови, называет два ключевых аспекта для оптимизации: укрепление эффективной логистики и лабораторной практики для избегания потерь по техническим причинам, а также доказательно обоснованные показания для трансфузии компонентов крови с целью избегания трансфузий без необходимости.

Важнейший аспект донорства - обеспечение безопасности. Риск для донора и реципиента, в особенности, в свете эпидемии ВИЧ, должен быть минимизирован за счет создания должных условий, включающих соответствующие помещения и обученный персонал. Ключевой момент в обеспечении безопасности - отбор донора. Рекомендации (95) 14 и (95) 15 предусматривают необходимость медицинского обследования донора, а также его детальное интервью, в ходе которого медицинский работник должен отсеять лиц, принадлежащих к категориям высокого риска передачи инфекционных заболеваний. К таким группам относят лиц с рискованным половым поведением, лиц, прибывших из эпидемиологически неблагополучных регионов, а также получавших лечение про-

\footnotetext{
${ }^{12}$ Бесплатная кровь: доноры и врачи о жизни по новым правилам // Аргументы и факты от 08.02.2013; Два месяца бесплатного донорства в России: катастрофы не случилось // Deautsche Welle от 21.03.2013; Путин предлагает вернуться к практике выплаты денежного вознаграждения донорам крови // ИТАР-ТАСС от 29.03.2013

${ }^{13}$ Schlumpf K.S. et al. Factors influencing donor return. Transfusion. 2008 Feb;48(2):264-72.

${ }^{14}$ Nguyen D.D. et al. Blood donor satisfaction and intention of future donation. Transfusion. $2008 \mathrm{Apr} ; 48(4): 742-8$.

${ }^{15}$ Masser B.M. et al. The psychology of blood donation: current research and future directions. Transfus Med Rev. 2008 Jul;22(3):215-33.
} 
DOI: $10.7256 / 1811-9018.2014 .12 .13523$

При цитировании этой статьи сноска на dоі обязательна

\section{Право и политика $12(180) \cdot 2014$}

дуктами крови и ее компонентами. Традиционную дискуссию вызывает возможность сдачи крови гомосексуалистами. Каких либо категорических требований на этот счет рекомендации СЕ не содержат. Более того, подход европейских государств к регулированию этого вопроса демонстрирует немалую пестроту: в большей части европейских государств установлены ограничения на допуск лиц указанной группы к донорству в форме постоянного запрета или временного отвода. Так, например, бессрочный запрет установлен во Франции, Германии, Австрии, Бельгии, ряде других государств; в Великобритании ранее действовавший полный запрет изменен на временный отвод сроком на год; в Италии и Испании запретов не установлено. Примечательно, что отвод от донорства крови установлен в некоторых государствах, весьма толерантно относящихся к гомосексуалистам. Так, например, в Андорре, где еще в 2005 году была разрешена регистрация гражданских союзов однополых пар, обсуждаемой категории лиц запрещено выступать донорами крови. Причем данный запрет был признан соответствующим Конституции решением Конституционного Суда Княжества Андорра ${ }^{16}$. Это важный прецедент, свидетельствующий о необходимости деполитизации данного вопроса и его перевода исключительно в здравоохранительную плоскость.

В России в соответствии с ранее действовавшим приказом Минздрава России от 14.09.2001 № 364 гомосексуализм до 2008 года был отнесен к числу абсолютных противопоказаний к донорству. Затем приказом Минздравсоцразвития России от 16.04.2008 № 175н указанная форма поведения была исключена из числа противопоказаний. Одновременно с этим указанный нормативный документ ввел требование того, чтобы донор должен быть отведен от донорства крови и ее компонентов, если при его обследовании и сборе его медицинского анамнеза, оценке общего состояния здоровья, а также связанного с ним образа жизни возникает подозрение на наркоманию или поведение, приводящее к риску заражения инфекционными заболеваниями, передаваемыми с кровью. Представляется, что указанная формула является более работоспособной по двум причинам: во-первых, данная формула позволяет отводить от донорской функции лиц как гомосексуальной, так и гетеросексуальной ориентации; во-вторых, установить принадлежность человека к лицам с указанной половой ориентацией кроме как на основании заявления самого опрашиваемого вряд ли возможно, что делало ранее действовавшее ограничение прав данной группы лиц формальным.

Следует заметить, что сегодня многие авторы отмечают важность совершенствования традиционной системы безопасности донорской крови, в связи с изменением характера жизни европейского общества. Так, С. de Mendoza et al. (2012) указывают на необходимость введения обязательного тестирования крови не только на ВИЧ, гепатиты (как это делается сегодня), но и на арбовирусы, такие как лихорадки Западного Нила, денге, чикунгунья, а также прионы, вызывающие болезнь Крейцфельда-Якоба («коровье бешенство», вспышка которого не так давно имела место в Великобритании - по

\footnotetext{
${ }^{16}$ Study on Homophobia, Transphobia and Discrimination on Grounds of Sexual Orientation and Gender Identity

Sociological Report: Andorra // http://www.coe.int/t/Commissioner/Source/ LGBT/AndorraSociological_E.pdf
}

данной теме Комитет Министров принял отдельные рекомендации 2001 (4) $)^{17}$. Повышенная мобильность общества, открытые границы создают совершенно новую конфигурацию вызовов и угроз в области здравоохранения. Своеобразным подтверждением сказанному может быть тот факт, что согласно современным данным, основанном на молекулярно-генетическом анализе, ВИЧ в Европу попал преимущественно из США и Центральной Африки ${ }^{18}$.

Особое внимание в рекомендациях уделено формированию системы качественной заготовки, оценке качества донорской крови и ее использования. Рекомендацией (95) 15 утверждено руководство по приготовлению, использованию и оценке качества компонентов крови. Данное руководство претерпело к настоящему моменту уже 17 переизданий и продолжает регулярно обновляться, становясь источником информации для специалистов национальных служб крови, включая российскую ${ }^{19}$.

Отдельный вопрос составляет практика Европейского Суда по правам человека по теме донорства крови, которая развивалась по двум основным направлениям. Первое из них связано с защитой права на отказ от медицинского вмешательства с применением крови и ее компонентов. Наиболее обстоятельно данный вопрос был рассмотрен Судом в деле Jehovah`s witnesses of Moscow and others v. Russia $(2010)^{20}$. Дело в том, что одним из оснований для запрета деятельности Свидетелей Иеговы в России, который и обжаловался заявителем, было указание на то, что приверженцы данного религиозного учения способствуют совершению другими членами самоубийства и (или) отказа от жизнесберегающего лечения (переливания крови, которое противоречит религиозной доктрине Свидетелей Иеговы). В связи с этим Суду надлежало оценить баланс между обязательствами государства по защите здоровья граждан и личной свободой, в том числе религиозной. ЕСПЧ отметил, что уважение человеческого достоинства и свободы, а также личной автономии являются важными принципами, которые лежат в основе интерпретации гарантий, предусмотренных Конвенцией. Возможность проживать жизнь по своему усмотрению предполагает, в частности, возможность совершать действия, могущие казаться опасными или вредными для индивида. Применяя данный подход к медицине, можно сказать, что принуждение дееспособного гражданина к определенному лечению, даже в случае, если неоказание помощи может иметь фатальные последствия, будет расцениваться как вмешательство в его право не личную неприкосновенность. Иными словами, свобода согласия на определенные виды лечения, равно как и поиск альтернативных форм составляют неотъемлемый элемент самоопределения и личной автономии. По этой причине в отсутствие более сильного законного интереса - необходимости защиты третьих лиц, государство должно воздерживаться от вмешательства в индивидуальные

\footnotetext{
${ }^{17}$ Mendoza de C. et al. Emerging viral infections -a potential threat for blood supply in the 21st century. AIDS Rev. 2012 Oct-Dec;14(4):279-89.

${ }^{18}$ Vermund S.H., Leigh-Brown A.J. The HIV Epidemic: High-Income Countries. Cold Spring Harb Perspect Med. 2012 May;2(5):a007195.

${ }^{19}$ Guide to the Preparation, Use and Quality Assurance of Blood Components. 17th Edition, CoE, 2013

${ }^{20}$ Jehovah's Witnesses of Moscow v. Russia, no. 302/02, § ..., 10 June 2010
} 
свободы в сфере охраны здоровья, поскольку такое вмешательство не увеличит, а уменьшит ценность человеческой жизни. Небезынтересно, что в своем решении Суд опирался на правоприменительную практику государственных судов, в частности, Верховного Суда Штата Онтарио (дело Malette v. Shulman (1990)), Апелляционного суда Великобритании (дело In re T. (1992)) ${ }^{21}$ и Окружного суда Штата Нью-Йорк (дело Fosmire v. Nicoleau (1990) ${ }^{22}$. В то же время решения российских судов по данному вопросу не стали источником вдохновения для ЕСПЧ, что, на наш взгляд, не вполне обосновано). Более того, как отметил ЕСПЧ в решении по делу Avilkina and Others v. Russia (2013) передача медицинскими учреждениями следственным органам сведений о том, что Свидетели Иеговы отказываются от переливания крови, является нарушением права на частную жизнь, гарантированного статьей 8 .

Второе направление практики ЕСПЧ в области донорства - нарушение прав, связанное с инфицированием ВИЧ в ходе переливания крови. В деле Oyal v. Turkey $(2010)^{23}$, истцами которого выступили родители ребенка (и сам ребенок), который в ходе переливания крови был заражен ВИЧ. Заявители указывали на нарушение права на жизнь ребенка (ст.2 ЕКПЧ), а также права на справедливое судебное разбирательство (ст.6 и ст.13). Суд отметил, что в случаях, когда нарушение права на жизнь произошло неумышленно, соответствующее возмещение может, как правило, происходить в рамках гражданского судопроизводства без привлечения уголовной юстиции. При причинении вреда при оказании медицинской помощи обязательства по защите права, предусмотренного статьей 2 , могут считаться исполненными, в случае, если правовая система предоставляет жертвам возможность получения возмещения только в рамках гражданского судопроизводства или же в совокупности с уголовным судопроизводством. В данном деле описываемое условие было соблюдено: национальный суд установил факты нарушений со стороны медиков и присудил компенсацию. Однако отсутствие справедливой компенсации (лечение пострадавшего легло тяжким бременем на его семью в отсутствии помощи со стороны властей) не позволяло говорить о выполнении позитивных обязательств по статье 2, что сохраняло за пострадавшими статус жертвы. Кроме того, длительность рассмотрения дела относительно ответственности Министерства здравоохранения Турции в непринятии мер по обеспечению безопасности крови составила более 9 лет, что с учетом ранее подчеркивавшейся Судом необходимости практической реализации права, гарантированного статьей 2, было сочтено нарушением Конвенции.

Суд также напомнил, что в делах, касающихся причинения вреда в ходе оказания медицинской помощи, оперативное расследование обстоятельств имеет ключевое значение для предотвращения аналогичных ошибок медперсонала (Šilih v. Slovenia (2009)). ${ }^{24}$ Примечательно, что в указанном деле Суд

\footnotetext{
${ }^{21}$ In re T. (Adult: Refusal of Treatment) 3 Weekly Law Reports 782 (Court of Appeal)

${ }^{22}$ Fosmire v. Nicoleau (75 N.Y.2d 218, 551 N.E.2d 77, 551 N.Y.S.2d 876 (1990)

${ }^{23}$ Oyal v. Turkey, no.4864/05, § ..., 23 March 2010

${ }^{24}$ Šilih v. Slovenia [GC], no. 71463/01, § 196, 9 April 2009
}

ссылался на рекомендации Комитета Министров, касающиеся предупреждения инфицирования ВИЧ при трансфузии, но не оперировал ими при формулировании своих выводов.

В настоящее время тематикой донорства крови в СЕ занимается Европейский комитет по переливанию крови (CD-P-TS), входящий с 2007 года в состав Европейского директората по качеству лекарственных средств и здравоохранению. Данный Комитет функционирует в рамках так называемого частичного соглашения - способа организации углубленного сотрудничества между государствами на платформе СЕ. В описываемом случае членами Комитета являются государства-стороны Конвенции о подготовке Европейской фармакопеи (Россия в число сторон не входит, однако наряду с другими нечленами может присутствовать на заседаниях в качестве наблюдателя). В задачи данного Комитета, определенные Комитетом Министров СЕ 3 и 4 февраля 2010 года, входит рассмотрение вопросов, касающихся переливания крови, в особенности стандартов качества и безопасности, вопросов этики, помощь странам-членам в применении стандартов, реструктурировании службы крови с тем, чтобы развить добровольное безвозмездное донорство, распространение знаний, оценка эпидемиологических рисков, установление наилучших практик, обеспечение доступности редких групп крови в Европе посредством различных инструментов, в частности, Европейского банка замороженной крови редких групп. Данный Комитет встречается не реже одного раза в год. За время своего существования он подготовил несколько отчетов по таким важным вопросам, как заготовка, тестирование и использование донорской крови в Европе, деятельности государств-членов СЕ по вопросу трансплантации костного мозга. Для исключения дублирования к участию в деятельности комитета приглашаются Европейская комиссия и представитель Всемирной организации здравоохранения.

Изложенное позволяет прийти к следующим выводам. В рамках СЕ тематика донорства крови и ее компонентов прорабатывается по нескольким основным направлениям: установление стандартов прав доноров и реципиентов (включая требования к информированию и согласию донора и реципиента), регулирование технических вопросов, связанных с обеспечением безопасности донорской крови (включая требования к заготовке, переработке, хранению, обеспечению безопасности и клиническому использованию крови и ее компонентов), взаимная помощь и сотрудничество государств-членов СЕ. Все указанные направления в конечном счете имеют своей целью защиту прав лиц, участвующих в правоотношениях, связанных с донорством крови и ее компонентов. В организационной модели Совета Европы действует отдельное структурное подразделение, занимающееся изучаемым вопросом. Выработанные стандарты формализуются в виде рекомендаций Совета Министров, а также решений ЕСПЧ.

Нельзя оставить без внимания вопрос соответствия действующего российского законодательства о донорстве крови стандартам СЕ. В 2012 году был принят новый Федеральный закон «О донорстве крови и ее компонентов», в котором нашли свое отражение принципы, выработанные Советом Европы в исследуемой области. Это имело положительный эффект не только на защищенность прав и свобод граждан, но и на саму службу крови: проводимый Министерством здравоохранения РФ силами ФМБА России регулярный 
DOI: $10.7256 / 1811-9018.2014 .12 .13523$

При цитировании этой статьи сноска на доі обязательна

\section{Право и политика $12(180) \cdot 2014$}

мониторинг показывает, что принятый Федеральный закон сыграл свою положительную роль: количество доноров крови увеличивается, равно как увеличивается и объем заготовленной крови. Вместе с тем, такое положение вещей не должно становиться препятствием на пути дальнейшего развития закона, основная цель которого - создать опти- мальные правовые условия для поступательного развития общественных отношений в сфере донорства крови в России. Это означает, что законодатель, должен находиться в постоянном поиске наиболее эффективных стимулов для привлечения новых лиц к донорству, а также возвращения регулярных доноров.

\section{Библиография:}

1. Charbonneau J., Tran N.Y. The symbolic roots of blood donation. Transfusion. 2013 Dec;53 Suppl 5:172S-9S.

2. Feldman E., Bayer R., ed. Blood feuds: AIDS, blood, and the politics of medical disaster. Oxford University Press. 1999,291 p.

3. Fosmire v. Nicoleau (75 N.Y.2d 218, 551 N.E.2d 77, 551 N.Y.S.2d 876 (1990)

4. Guide to the Preparation, Use and Quality Assurance of Blood Components. 17th Edition, CoE, 2013

5. $\quad$ In re T. (Adult: Refusal of Treatment) 3 Weekly Law Reports 782 (Court of Appeal)

6. Jehovah's Witnesses of Moscow v. Russia, no. 302/02, § ..., 10 June 2010

7. Likatavicius G. et al. Trends in HIV prevalence in blood donations in Europe, 1990-2004.AIDS. 2007 May 11;21(8):1011-8.

8. Love S. One Blood: The Death and Resurrection of Charles R. Drew. University of North Carolina Press, 1996. 373 p.

9. Masser B.M. et al. The psychology of blood donation: current research and future directions. Transfus Med Rev. 2008 Jul;22(3):215-33.

10. Mendoza de C. et al. Emerging viral infections-a potential threat for blood supply in the 21st century. AIDS Rev. 2012 Oct-Dec;14(4):279-89.

11. Needham R. Blood, thunder and mockery of animals. Sociologus. 1964. 14 (2): 136-149

12. Nguyen D.D. et al. Blood donor satisfaction and intention of future donation. Transfusion. 2008 Apr;48(4):742-8.

13. Oyal v. Turkey, no. $4864 / 05, \S$..., 23 March 2010

14. Schlumpf K.S. et al. Factors influencing donor return. Transfusion. 2008 Feb;48(2):264-72.

15. Šilih v. Slovenia [GC], no. 71463/01, § 196, 9 April 2009

16. Sociological Report: Andorra // http://www.coe.int/t/Commissioner/Source/LGBT/AndorraSociological_E.pdf

17. Statute of the Council of Europe, London, 5.V.1949

18. Study on Homophobia, Transphobia and Discrimination on Grounds of Sexual Orientation and Gender Identity

19. Suligoi B. et al.Epidemiology of human immunodeficiency virus infection in blood donations in Europe and Italy. Blood Transfus. 2010 Jul;8(3):178-85. doi: 10.2450/2009.0126-09.

20. Turner V. The forest of symbols: Aspects of Ndembu ritual. Cornell University Press. 1967, 405 p.

21. Vermund S.H., Leigh-Brown A.J.The HIV Epidemic: High-Income Countries. Cold Spring Harb Perspect Med. 2012 May;2(5):a007195.

22. Бесплатная кровь: доноры и врачи о жизни по новым правилам // Аргументы и факты от 08.02.2013;

23. Два месяца бесплатного донорства в России: катастрофы не случилось // Deautsche Welle от 21.03.2013;

24. Путин предлагает вернуться к практике выплаты денежного вознаграждения донорам крови // ИТАР-ТАСС от 29.03.2013

25. Р. А. Гурбанов Правовые основы взаимодействия государств-членов Совета Европы в сфере правосудия // Политика и Общество. 2011. - 8. - C. $9-14$.

\section{References (transliterated):}

1. Charbonneau J., Tran N.Y. The symbolic roots of blood donation. Transfusion. 2013 Dec;53 Suppl 5:172S-9S.

2. Feldman E., Bayer R., ed. Blood feuds: AIDS, blood, and the politics of medical disaster. Oxford University Press. 1999,291 p.

3. Jehovah's Witnesses of Moscow v. Russia, no. 302/02, § ..., 10 June 2010

4. Likatavicius G. et al. Trends in HIV prevalence in blood donations in Europe, 1990-2004.AIDS. 2007 May 11;21(8):1011-8.

5. Love S. One Blood: The Death and Resurrection of Charles R. Drew. University of North Carolina Press, 1996. 373 p.

6. Masser B.M. et al. The psychology of blood donation: current research and future directions. Transfus Med Rev. 2008 Jul;22(3):215-33.

7. Mendoza de C. et al. Emerging viral infections-a potential threat for blood supply in the 21st century. AIDS Rev. 2012 Oct-Dec;14(4):279-89.

8. Needham R. Blood, thunder and mockery of animals. Sociologus. 1964. 14 (2): 136-149

9. $\quad$ Nguyen D.D. et al. Blood donor satisfaction and intention of future donation. Transfusion. 2008 Apr;48(4):742-8.

10. Oyal v. Turkey, no.4864/05, § ..., 23 March 2010

11. Schlumpf K.S. et al. Factors influencing donor return. Transfusion. 2008 Feb;48(2):264-72.

12. Suligoi B. et al.Epidemiology of human immunodeficiency virus infection in blood donations in Europe and Italy. Blood Transfus. 2010 Jul;8(3):178-85. doi: 10.2450/2009.0126-09.

13. Turner V. The forest of symbols: Aspects of Ndembu ritual. Cornell University Press. 1967, $405 \mathrm{p}$.

14. Vermund S.H., Leigh-Brown A.J.The HIV Epidemic: High-Income Countries. Cold Spring Harb Perspect Med. 2012 May;2(5):a007195.

15. R. A. Gurbanov Pravovye osnovy vzaimodeistviya gosudarstv-chlenov Soveta Evropy v sfere pravosudiya // Politika i Obshchestvo. - 2011. 8. - C. $9-14$. 